\title{
A CHECKLIST OF FREE-LIVING MARINE NEMATODES AT DIFFERENT ECOSYSTEM IN NORTHERN STRAITS OF MALACCA, MALAYSIA
}

\author{
ShaKila SAmad ${ }^{1}$, Mahadi MohammaD ${ }^{1,2}$, SAZlina SAlleH $^{3}$, AqILAH DariF $^{3}$ \\ ${ }^{1}$ School of Biological Sciences, Universiti Sains Malaysia, Penang, 11800, Malaysia \\ ${ }^{2}$ Centre for Marine and Coastal Studies, Universiti Sains Malaysia, Penang 11800, Malaysia \\ ${ }^{3}$ Centre for Policy Research and International Studies, Universiti Sains Malaysia, Penang, 11800, Malaysia
}

\section{A BST RACT}

Nematodes present in all substrates and sediment types with an enormous number of species. The studies on free-living marine nematodes are still limited in Malaysia. The present study provides general information on genus checklist of free-living marine nematodes in the northern part of Peninsular Malaysia in a different ecosystem which are intertidal zones of estuarine, sandy beach and mangrove ecosystems. Samples were randomly collected at three stations in each ecosystem. A total of 34 genera (22 families and ten suborders) were recorded in three ecosystems. Each ecosystem had common genera which also commonly found worldwide. Viscosia genus was observed in all three ecosystems. The nematode genera of Estuary and mangrove ecosystems had greater similarities than those in the sandy beach.

KEY WORDS: nematodes checklist, Peninsular Malaysia, sandy beach, estuarine, mangrove

\section{N T R O D U C T I O N}

Nematodes are wormlike unsegmented invertebrate organisms live in terrestrial, marine, and freshwater ecosystems. The majority of nematode species are free-living in terrestrial soils and aquatic sediments, primarily occupy all soft sediment ecosystems and, even in lower abundances, biofilms on secondary and/or hard substrates (Moens et al., 2013). Marine nematodes usually are of a meiofaunal size, which passes through a $500 \mu \mathrm{m}$ sieve, but is retained on mesh sieve of 31-42 $\mu \mathrm{m}$; only some are larger, such as some enoplids and oncholaimids (Tahseen, 2012).

Nematode abundances are higher in the upper centimeters of the sediment (Moens et al., 2013). Its abundance and diversity differ among different ecosystems. Mudflat and sandy ecosystems have different assemblages with unique characteristics. Nematodes from sandy ecosystem are slenderer because they have to move through the interstitial gap while nematodes from mudflat ecosystem are more robust to burrow through the sediment (Tita et al., 1999). In enriched estuarine, muddy sediment is characterized by a high density of nematodes $(>3,000$ individuals per $10 \mathrm{~cm}^{2}$ ) (Heip et al., 1985).

Studies on free-living marine nematodes in Malaysia are limited, particularly in regard to taxonomical studies (Rosli et al., 2010). Only a few researchers have been concentrated on free-living marine nematodes in Malaysia (Chen et al. 2012a; Chen et al. 2012b; Rosli et al. 2013). The studies in Malaysia are mostly on the ecology and diversity of meiobenthos (Sasekumar, 1994; Somerfield et al. 1998; Ibrahim et al. 2006; Long, 2006).

Thus, the major aim of this study was to establish a checklist of free-living marine nematodes in different habitats which were a sandy beach, mangrove, and estuarine ecosystems in northern Straits of Malacca. This research can also be used as a baseline for future studies and provide an overview of the nematodes assemblage in different ecosystems along the northern Straits of Malacca.

\section{METHODS}

Tanjung Rhu is situated on the northeast coast of Pulau Langkawi, Kedah (about 6²7'3.10”N, 99.49¹8.80”E) (Figure 1). It is an estuary area leading towards the open sea, and relatively undisturbed even though there are several developments within the region. Tanjung Rhu is suitable for this study due to its relatively pristine condition There are few natural ecosystems in this study which include coral reefs, mudflats, mangrove, sandflats and an estuarine-riverine system. This study focused on estuarineriverine ecosystems which consist of mudflat surrounded by mangroves and a sandy brackish zone whereby the estuarine water flows towards the open sea.

Teluk Aling is located at the northwest tip of Penang (Figure 1), at $5^{\circ} 28^{\prime} 03.7^{\prime \prime} \mathrm{N} 100^{\circ} 11^{\prime} 59.3^{\prime \prime}$ E. Universiti Sains Malaysia (USM) research center, CEMACS (Centre for Marine and Coastal Studies) has been established in Teluk Aling since the middle of the 1970s. It consists of a small area of sand flat supported by a hill (average slope of $30^{\circ}$ ) of Dipterocarpus forest with no freshwater input except through seepage and surface runoff. The tidal cycle is semidiurnal with extreme ranges of 0.2-2.9 m above chart datum (Ong \& Krishnan, 1995). Litters and campfires from the research center can be seen along the Teluk Aling. The samples were taken along the sandy shores in front of CEMACS.

Kuala Sepetang is on the west coast of peninsular Malaysia in the state of Perak (Figure 1), and situated at $4^{\circ} 50^{\prime} 37.7^{\prime \prime} \mathrm{N} 100^{\circ} 38^{\prime} 00.5^{\prime \prime} \mathrm{E}$. The mangroves are the dominant feature of the coastline, which is almost entirely flat for miles around. The Sepetang River brings down the main riverine discharge from upstream, and there were few fish cages located near the river mouth (Ghaderpour et al., 2014). 


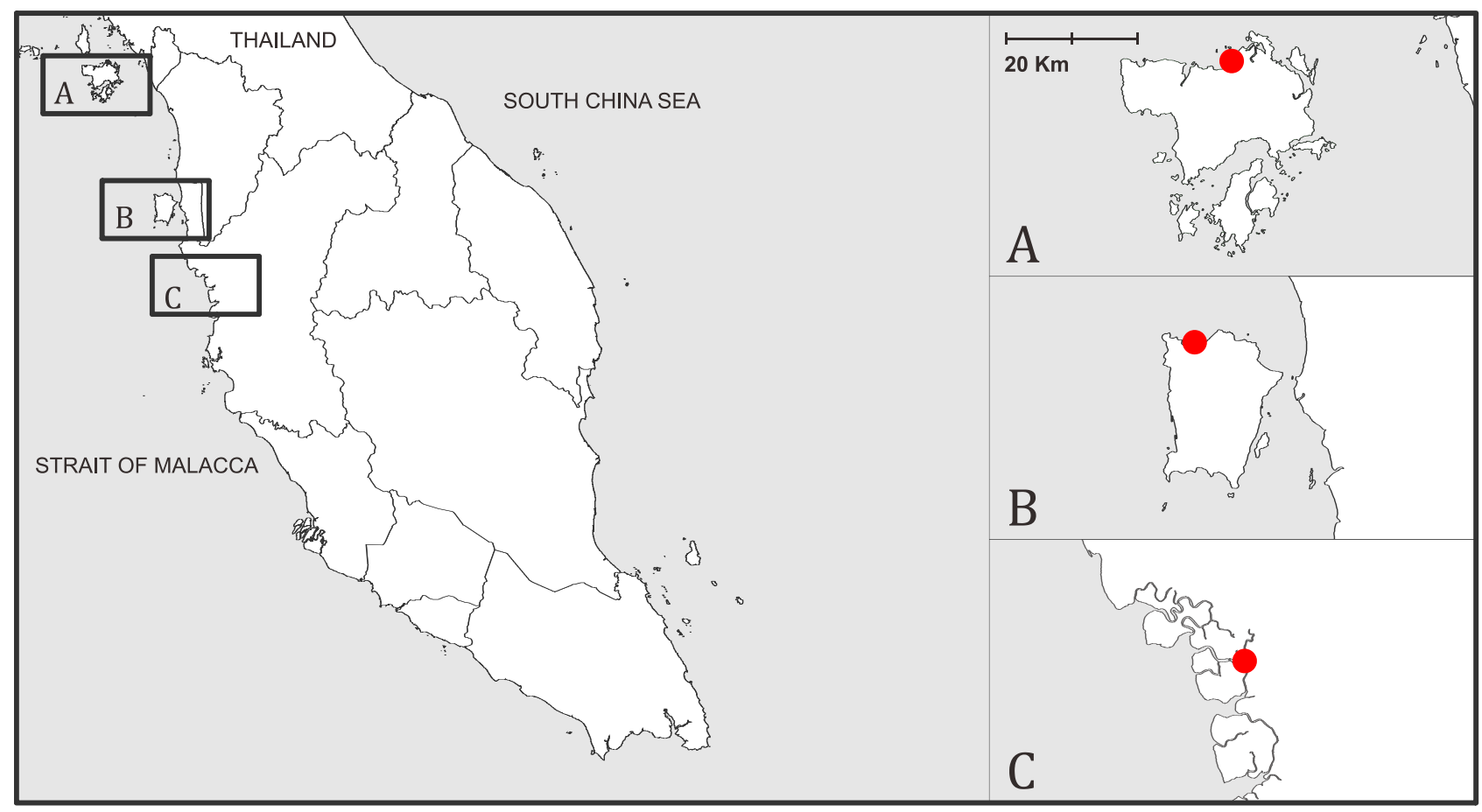

Figure 1. The map of Peninsular Malaysia showing the sampling locations which were Pulau Langkawi, Kedah (A); Penang (B), and Perak (C). Map of Tanjung Rhu (estuary), Langkawi; Teluk Aling (sandy beach), Penang; and Kuala Sepetang (mangrove), Perak respectively

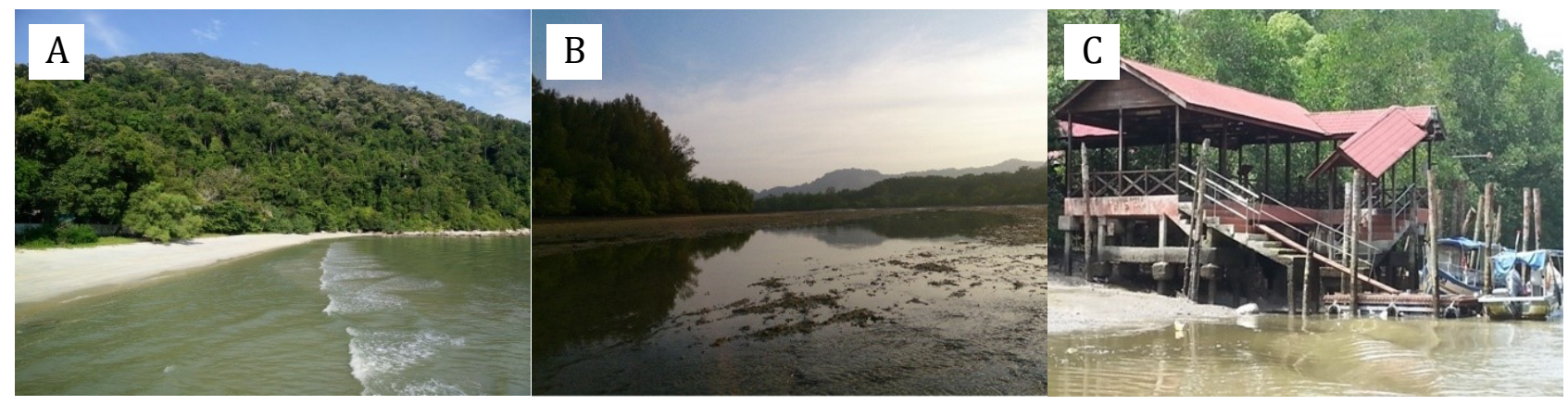

Figure 2. Photos of three sampling sites, (A) Teluk Aling (sandy beach); (B) Tanjung Rhu (estuarine); (C) Kuala Sepetang (mangrove)

It supports a variety of aquaculture products as the warm tropical weather, and healthy mangroves provide nursery grounds for marine organisms (Ghaderpour, 2013). The sampling was taken near the jetty of Kuala Sepetang.

Sampling was done in three different ecosystems which were sandy beach (Teluk Aling), mangrove (Kuala Sepetang) and estuarine (Tanjung Rhu) as shown in Figure 2, to determine the composition of marine nematodes in different ecosystems. Sediment samples $(n=4)$ were collected at 5 $\mathrm{cm}$ depth from the surface by using PVC core tubes $(50 \mathrm{~mm}$ height $\times 35 \mathrm{~mm}$ diameter) from three ecosystems. There were three sites in each ecosystem with three replicates in each site. The sediment collected was sieved through using two mesh sieves. The pore size of the top sieve was $450 \mu \mathrm{m}$, and the pore of the bottom sieve was $32 \mu \mathrm{m}$. The sample trapped in bottom sieve was transferred into $50 \mathrm{~mL}$ of the plastic jar. The samples were preserved in $70 \%$ alcohol and stained with $2.5 \mathrm{~mL}$ of Rose Bengal solution.

Extraction of free-living marine nematodes was done using the modified method of Heip et al. (1985) which was Ludox centrifugation technique. Samples $(20 \mathrm{~mL})$ were transferred into $50 \mathrm{~mL}$-centrifuge tubes and $20 \mathrm{~mL}$ of Ludox solution was added to each of the tubes. The mixture was shaken to allow proper mixing of sample and Ludox solution. The sample in centrifuge tube was left for 10 minutes to let the sediment to settle. The supernatant containing nematodes was drained into a $32 \mu \mathrm{m}$-sieve and washed. This step was repeated for three times to ensure nematodes were entirely extracted from the sediment. The nematodes were sorted by using stereomicroscope and kept in a $2 \mathrm{~mL}$-centrifuge tube that contained glycerol-ethanol (ratio 4:1) mixture with $1 \%$ of Rose Bengal before the microscope examination.

Permanent microscope slides were made using the method suggested by Ryss (2003). The slides were observed under the light microscope (Olympus BX41, Xcam Alpha, Image Processing software, version 5.1) 1000X magnifications. The photos were taken for the identification of nematodes (Figure 3). The nematodes were identified to the highest possible taxon using Warwick et al. (1998).

\section{RESULTS AND DISCUSSIONS}

A total of 34 genera had been recorded and sorted into four Orders (Enoplida, Trefusiida, Chromadorida, and Monhysterida) in three ecosystems where estuary 
ecosystem (Tanjung Rhu) composed of 16 genera, sandy beach ecosystem (Teluk Aling) was eight genera, and mangrove ecosystem (Kuala Sepetang) included 15 genera.

Eleven families of marine nematode from the suborder Chromadorina, Desmodorina, Ironina, Desmoscolecina, Oncholaimina, Monhysterina, and Ceramonematina were recorded in the estuary. A total of eight families under the order of Araeolaimida, Chromadorida. Desmodorida, Enoplida, Monhysterida, and Plectida had been identified in the sandy beach while 14 families from seven suborders (Chromadorina, Desmodorina, Enoplina, Ironina, Oncholaimina, Trefusiina, and Monhysterina) had been recorded in the mangrove (Table 1 ).

In an estuarine ecosystem with gravelly sand type sediment, Paradesmodora and Spilophorella were the dominant genera. While in sandy beach ecosystem with sand type sediment, Microlaimus, Odontophora, and Onyx dominated. In mangrove ecosystem with sandy mud type sediment, Sphaerolaimus and Daptonema were dominant (Figure 4). Furthermore, Viscosia has been observed in all three ecosystems. There were four genera (Spilophorella, Daptonema, Parodontophora, and Viscosia) presented in both estuary and mangrove, whereas only two genera (Onyx and Viscosia) lived in both sandy beach and estuary. There were no similar genera observed in both mangrove and sandy beach.

Some free-living marine nematode species are common to mudflat and sandy ecosystem and most of them are usually mud- or sand-preferring (Heip et al. 1985; Semprucci et al. 2010). Microlaimus and Odontophora were the dominant genera in sandy beach ecosystem. It has been reported in several studies that, in clean sand, genera that are commonly encountered are Bathylaimus, Nudora, Odontophora, Paracanthonchus, Paracyatholaimus and Microlaimus (Lee \& Riveros, 2011; Fonseca \& Fehrlauer-Ale, 2012). The genus Microlaimus also dominate sandy beach according to studied by Liu et al. (2008) in China.

Families such as Comesomatidae, Linhomoeidae and Sphaerolaimidae and some genera (Sabatiera, Sphaerolaimus, Terschellingia, and Daptonema) usually dominate mudflat sediments (Travizi, 2010). A recent study by Bhadury et al. (2015) on nematode assemblages in the central west coast of India had similar findings. In this study, Sphaerolaimus and Daptonema had dominated mangrove habitat comprising of mudflat sediments.

In the present study, Viscosia was the only genus found in all three ecosystems as it was listed as one of the common genera to all environments (Venekey et al., 2010). A study done by Long et al. (2010) in Sarawak, Malaysia on the distribution of nematodes in the intertidal area found that Daptonema genus was more abundant in mudflat sediment compared to sandy sediment. The Daptonema genus which was found in both estuary and mangrove ecosystems had dominated mangrove ecosystem that had a high percentage (90\%) of mud sediment. The presence of Daptonema genus in mudflat sediment was due to the type of food sources and its feeding type (Long et al., 2010). Food sources such as bacteria or microalgae were abundant in mudflat sediment, and Daptonema which has been characterized as 1B (non-selective feeder) mostly consumed bacteria and microalgae.

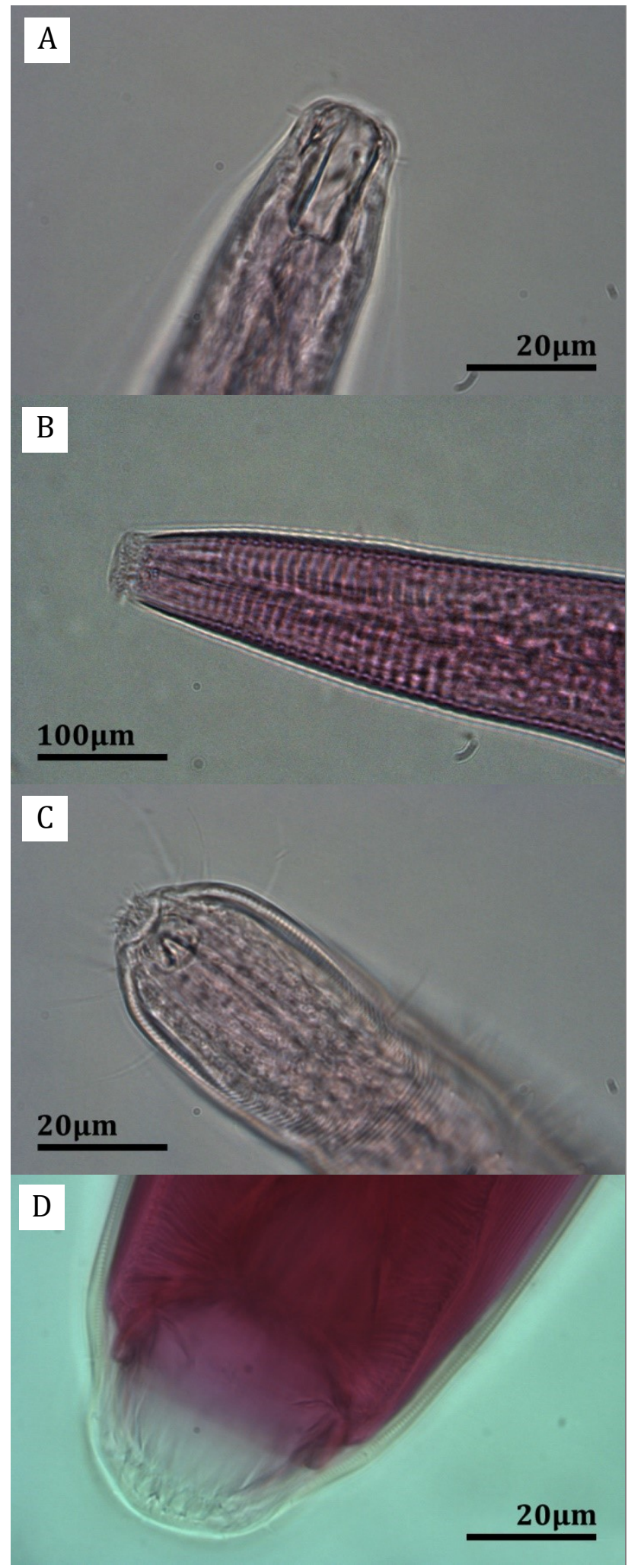

Figure 3. Photos of marine nematodes, (A) Viscosia; (B) Spilophorella; (C) Onyx; (D) Sphaerolaimus 
Table 1. Order, suborder, family, and genus of free-living marine nematodes recorded in three different ecosystems

\begin{tabular}{|c|c|c|c|c|c|c|}
\hline Order & Suborder & Family & Genus & $\begin{array}{c}\text { Sandy } \\
\text { Beach } \\
\text { TelukAling }\end{array}$ & $\begin{array}{c}\text { Mangrove } \\
\text { Kuala } \\
\text { Sepetang }\end{array}$ & $\begin{array}{c}\text { Estuarine } \\
\text { Tanjung } \\
\text { Rhu }\end{array}$ \\
\hline \multirow[t]{6}{*}{ Araeolaimida } & & Axonolaimidae & AxonolaimusDe Man, 1889 & - & + & - \\
\hline & & & ParodontophoraTimm, 1963 & - & + & + \\
\hline & & & OdontophoraBütschii, 1874 & + & - & - \\
\hline & & Comesomatidae & HopperiaVitiello, 1969 & - & + & - \\
\hline & & & SabatieraRouville, 1903 & - & - & + \\
\hline & & Diplopeltidae & SoutherniellaAllgén, 1932 & - & + & - \\
\hline \multirow[t]{6}{*}{ Chromadorida } & Chromadorina & Chromadoridae & GomphionemaWieser\& Hopper, 1996 & - & - & + \\
\hline & & & LatronemaWieser, 1954 & - & - & + \\
\hline & & & Ritchersia Steiner, 1916 & - & - & + \\
\hline & & & SpilophorellaFilipjev, 1917 & - & + & + \\
\hline & & & Ptycholaimellus Cobb, 1920 & + & - & - \\
\hline & & Cyatholaimidae & ParacyatholaimusMicoletzky, 1922 & - & + & - \\
\hline \multirow[t]{6}{*}{ Desmodorida } & Desmodorina & Desmodoridae & ChromaspirinaFilipjev, 1922 & - & - & + \\
\hline & & & Onyx Cobb, 1891 & + & - & + \\
\hline & & & ParadesmodoraStekhoven, 1950 & - & - & + \\
\hline & & & Spirinia Gerlach, 1963 & - & - & + \\
\hline & & Microlaimidae & Microlaimus De Man, 1880 & + & - & - \\
\hline & & Monoposthiidae & Nudora Cobb, 1920 & - & + & - \\
\hline Desmoscolecida & Desmoscolecina & Desmoscolecidae & QuadricomaFilipjev, 1922 & - & - & + \\
\hline \multirow[t]{7}{*}{ Enoplida } & Enoplina & Anosplostomatidae & AnoplostomaBütschli, 1874 & - & + & - \\
\hline & Ironina & Ironidae & Trissonchulus Cobb,1920 & - & + & - \\
\hline & & Oxystominidae & Halalaimus De Man, 1888 & - & - & + \\
\hline & & & Wieseria Gerlach, 1956 & - & + & - \\
\hline & Oncholaimina & Oncholaimidae & Viscosia De Man, 1890 & + & + & + \\
\hline & & Enchelidiidae & Bathyeurystomina Lambshead \& Platt, 1979 & - & + & - \\
\hline & Trefusiina & Trefusiidae & Rhabdocoma Cobb, 1920 & - & + & - \\
\hline \multirow[t]{5}{*}{ Monhysterida } & Linhomoeina & Linhomoeidae & Eleutherolaimus Schulz, 1932 & + & - & - \\
\hline & Monhysterina & Sphaerolaimidae & Sphaerolaimus Bastian, 1865 & - & + & - \\
\hline & & Xyalidae & Daptonema Cobb, 1920 & - & + & + \\
\hline & & & Rhynchonema Cobb, 1920 & - & - & + \\
\hline & & & Scaptrella Cobb, 1917 & + & - & - \\
\hline \multirow[t]{2}{*}{ Plectida } & Ceramonematina & Ceramonematidae & Metadasynemella De Connick, 1942 & - & - & + \\
\hline & & Tubolaimoididae & Chitwoodia Gerlach, 1965 & + & - & - \\
\hline Total & & & & 8 & 15 & 16 \\
\hline
\end{tabular}

Notes: (+) present, (-) absent

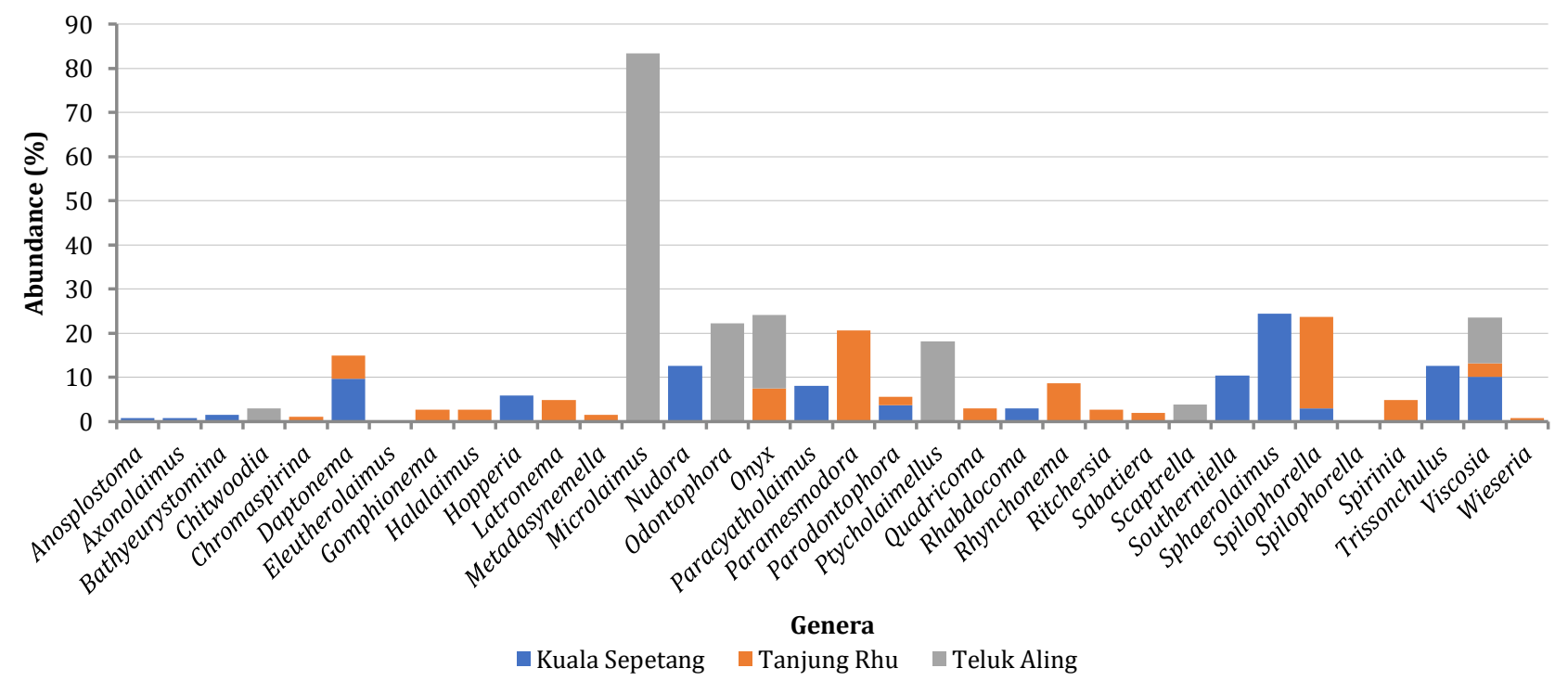

Figure 4. The abundance (\%) of genera in each ecosystem

A review by Heip et al. (1985) states that several nematode genera common in many estuarine ecosystems were Adoncholaimus, Anoplostoma, Axonolaimus, Daptonema, Leptolaimus, Microlaimus, Monhystera, Metachromadora, Ptycholaimellus, Sabatieria, Theristus, Tripyloides, and Viscosia. In a different study, Quang et al. (2010) found other genera that were also present in high abundance in the Mekong estuarine ecosystem, i.e., Halalaimus, Rhynchonema, Parodontophora, Terschellingia, Desmodora, Onyx, Leptolaimoides, Oncholaimellus, Omicronema, Rhinema, and Haliplectus. However, in our study, Spilophorella, Onyx, Rhynchonema, Viscosia, and Paredesmodora were present in high abundance (Figure 2) in the estuarine ecosystem. 


\section{CONCLUSION}

A total of 34 genera of free-living marine nematodes had been recorded in three different ecosystems along the northern Straits of Malacca. This free-living marine nematodes checklist provides an outline for undertaking future studies on the biogeography of marine nematodes and studies of their relative distribution trends. This checklist is the baseline for future observation of anthropogenic changes in Peninsular Malaysia.

\section{AC KN OWLEDGMENT}

Gratitude is expressed to MOSTI Flagship Grant (304.CDASAR.650724.p131) and Research Grant from USM-RUI (1001.PBIOLOGI.811245) that supported our project.

\section{REFERENCES}

Bhadury P, Mondal N, Ansari KGMT, Philip P, Pitale R, Prasade A, Nagale P, Apte D. 2015. Checklist of free-living marine nematodes from intertidal sites along the central west coast of India. Check List Journal. 11(2): 1605.

Chen C-A, Long SM, Rosli NM. 2012a. An ecological study of freeliving marine nematodes in Teluk Awar, Sarawak, Malaysia. Borneo Journal of Resource Science and Technology. 2(1): 1-10.

Chen C-A, Long SM, Rosli N. 2012b. Spatial distribution of tropical estuarine nematode communities in Sarawak, Malaysia (Borneo). The Raffles Bulletin of Zoology. 60(1): 173-181.

Fonseca G, Fehrlauer-Ale K. 2012. Three in one: fixing marine nematodes for ecological, molecular and morphological studies. Limnol. Oceanogr. Methods10: 516-523.

Ghaderpour A. 2013. Evaluation of microbiological quality and safety in Kuala Sepetang estuaries (Perak, Malaysia) using cultivation-dependent method [doctoral dissertation]. University of Malaya.

Ghaderpour A, Nasori KNM, Chew LL, Chong VC, Thong KL, Chai LC. 2014. Detection of multiple potentially pathogenic bacteria in Matang mangrove estuaries, Malaysia. Marine pollution bulletin. 83(1): 324-330.

Heip CHR, Vincx M, Vranken G. 1985. The ecology of marine nematodes. Aberdeen University Press.

Ibrahim S, Wan Hussin WMR, Kassim Z, Joni ZM, Zakaria MZ, Hajisamae S. 2006. Seasonal abundance of benthic communities in coral areas of Karah Island, Terengganu, Malaysia. Turkish Journal of Fisheries and Aquatic Sciences. 6: 129-136.

Lee M, Riveros M. 2011. Latitudinal trends in the species richness of free-living marine nematode assemblages from exposed sandy beaches along the coast of Chile $\left(18-42^{\circ} \mathrm{S}\right)$. Marine Ecology. 33: 317-325.
Liu X-S, Xu W-Z, Cheung SG, Shin PKS. 2008. Subtropical meiobenthic nematode communities in Victoria Harbour, Hong Kong. Marine Pollution Bulletin. 56(8): 1491-1497.

Long SM. 2006. Marine and estuarine meiofauna of Sarawak, Malaysia-A review. The Sarawak Museum Journal. 201-222.

Long SM, Bujang S, Mohamad. 2010. Distribution of intertidal nematode from western Sarawak, Malaysia. The Sarawak Museum Journal. 88: 189-207.

Moens T, Braeckman U, Derycke S, Fonseca G, Gallucci F, Ingels J, Leduc D, Vanaverbeke J, Van Colen C, Vanreusel A, Vincx M. 2013. Ecology of free-living marine nematodes. In: Andreas Schmidt-Rhaesa, editor. Handbook of Zoology: p. 109-152.

Ong B, Krishnan S. 1995. Changes in the macrobenthos community of a sand flat after erosion. Estuarine, Coastal and Shelf Science. 40(1):21-33.

Quang NX, Vanreusel A, Smol N, Chau NN. 2010. Meiobenthos assemblages in the Mekong estuarine system with special focus on free-living marine nematodes. Ocean Science Journal. 45(4): 213-224.

Rosli NM, Long SM, Chen C-A. 2010. Free-living marine nematodes from Niah River estuary, Sarawak. In: Sahrani FK, Latif TM, Usup G, Othman MR, editors. Proceedings of Marine ecosystems: management of resources for human \& environmental well-being; 2010 Jun 22-24; Pahang. EKOMAR; p.49-59.

Rosli NM, Long SM, Cheng CA. 2013. A new record from east Malaysia: Sphaerolaimus macrocirculus (Nematoda). Borneo Journal of Resource Science and Technology 2(2):12-18.

Ryss AY. 2003. Express technique to prepare permanent collection slides of nematodes. Zoosystematica Rossica, 11(2):257-260

Sasekumar A. 1994. Meiofauna of a mangrove shore on the west coast of peninsular Malaysia. The Raffles Bulletin of Zoology. 42(4): 901-915.

Semprucci F, Colantoni P, Baldelli G, Rocchi M, Balsamo M. 2010. The distribution of meiofauna on back-reef sandy platforms in the Maldives (Indian Ocean). Marine Ecology. 31(4): 592-607.

Somerfield PJ, Gee JM, Aryuthaka C. 1998. Meiofaunal communities in a Malaysian mangrove forest. J. Mar. Biol. Ass. U.K. 78: 717732.

Tahseen Q. 2012. Nematodes in aquatic environments: adaptations and survival strategies. Biodiversity Journal. 3(1): 13-40.

Tita G, Vincx M, Desrosiers G. 1999. Size spectra, body width and morphotypes of intertidal nematodes: an ecological interpretation. J. Mar. Biol. Assoc. U.K. 79: 1007-1015.

Travizi A. 2010. The nematode fauna of the northern Adriatic offshore sediments: community structure and diversity. Acta Adriat. 51(2): 169-180.

Venekey V, Fonseca-Genevois VG, Santos PJP. 2010. Biodiversity of free-living marine nematodes on the coast of Brazil: a review. Zootaxa. 2568: 39-66.

Warwick RM, Platt HM, Somerfield PJ. 1998. Freeliving marine nematodes: Part III. Monhysterida. Synopses of the British Fauna No.53. 